\title{
Insect Pest Managment Services Provided by Bats ${ }^{1}$
}

Holly K. Ober ${ }^{2}$

Thirteen different species of bats live in Florida year-round. All of them sleep in roosts during the day and emerge at dusk to feed on insects throughout the night. Due to their small size and high metabolism, bats have exceptionally high energy demands. This means that each bat consumes large quantities of insects. During the summer, when pregnant and nursing female bats have especially high energy requirements, each bat may consume as much as two thirds of its body weight per night. This would be the equivalent of a 150-pound human consuming 100 pounds of food per day!

Some bat species live alone, whereas other species prefer to live in large groups. The largest bat colony in Florida is estimated to contain 100,000 individuals. This colony is located in the house specially built for bats on the campus of the University of Florida in Gainesville. Large colonies like this can have a great impact on insect populations nearby.

\section{Can Bats Reduce Insect Damage to Agricultural Crops?}

Bats consume insects that are major pests of agricultural crops. Several species that occur in

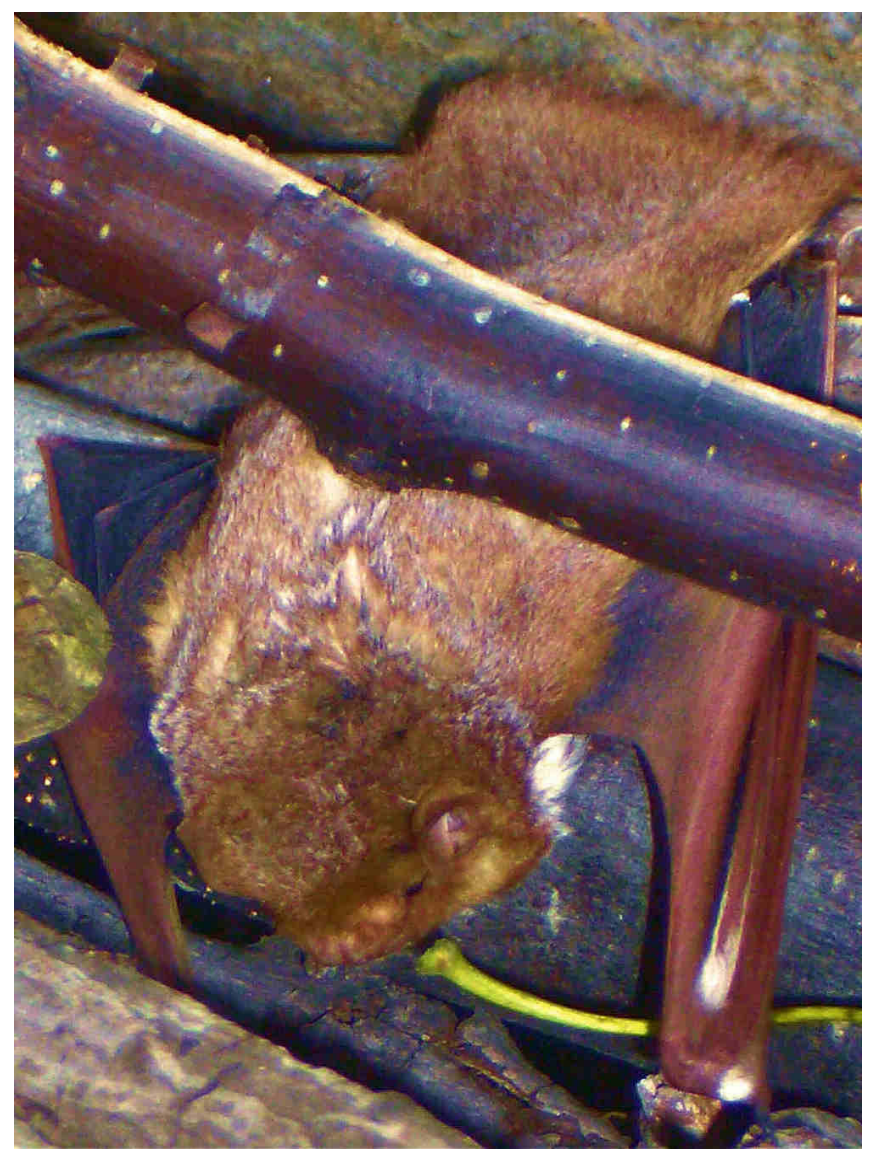

Figure 1. Bats are voracious consumers of insects that may help reduce local populations of some insect pests. Credits: Theodore Fisher (2006).

1. This document is WEC245, one of a series of the Wildlife Ecology and Conservation Department, Florida Cooperative Extension Service, Institute of Food and Agricultural Sciences, University of Florida. Original publication date August 2008. Visit the EDIS website at http://edis.ifas.ufl.edu.

2. Holly K. Ober, assistant professor and extension specialist, Department of Wildlife Ecology and Conservation, University of Florida, IFAS, at the North Florida Research and Education Center, 155 Research Rd, Quincy, Florida 32351

The Institute of Food and Agricultural Sciences (IFAS) is an Equal Opportunity Institution authorized to provide research, educational information and other services only to individuals and institutions that function with non-discrimination with respect to race, creed, color, religion, age, disability, sex, sexual orientation, marital status, national origin, political opinions or affiliations. U.S. Department of Agriculture, Cooperative Extension Service, University of Florida, IFAS, Florida A. \& M. University Cooperative Extension Program, and Boards of County Commissioners Cooperating. Millie Ferrer-Chancy, Interim Dean 
Florida have been reported to play important roles in reducing crop damage in other states.

A species found in Florida called the big brown bat (Eptesicus fuscus) consumes a number of insect pests that cause damage to corn, soybean, cotton and other crops in the Midwest. Insects consumed by the big brown bat include spotted cucumber beetles and their larval form, rootworms (Diabrotica undecimpunctata); green stinkbugs (Acrosternum hilare); and leafhoppers (Draeculacephala spp).

Studies have not yet been done to determine whether these bats consume the same insect pests in Florida as they do in the Midwest.

Another species of bat, the Mexican free-tailed bat (Tadarida brasiliensis mexicana), consumes several species of moths that are agricultural pests in Texas. They eat the fall armyworm (Spodoptera frugiperda), cabbage looper (Trichoplusia ni), tobacco budworm (Heliothis virescens), and corn earworm or cotton bollworm (Helicoverpa zea). The southeastern version of this bat, the Brazilian free-tailed bat (Tadarida brasiliensis cynocephala), is common throughout Florida, and tends to live in very large colonies. Studies are currently under way to determine whether these bats consume the same insect pests in the Southeast as they do in Texas.

Researchers have estimated the economic value of the pest control services Mexican free-tailed bats provide in Texas. DNA tests have confirmed that these bats regularly consume the corn earworm moth during the early part of the growing season in this state. Experts estimate that approximately 100 million bats occur in an eight-county region of south-central Texas, and these bats can consume 4 billion corn earworm moths per night! These bats have the potential to reduce the need for one or two insecticide applications each year, which could reduce costs by $\$ 19 /$ acre on conventional cotton fields and \$35/acre on transgenic cotton fields (costs reported in 2007). The total financial contribution of the bats was determined by estimating the value of the cotton crop that would have been lost if bats were not present, plus the cost of insecticides that would have been needed if bats had not consumed any insect pests, plus the social and environmental costs saved by the reduced use of insecticides. The value of the pest control services bats provide for cotton producers in south-central Texas was estimated to be $\$ 741,000$ per year. Similar estimates have not yet been made in the Southeast.

\section{Can Bats Control Mosquitoes?}

Most species of bats feed on a wide variety of insects. The three orders of insects most commonly consumed by bats in the United States are moths (Lepidoptera), beetles (Coleoptera), and flies (Diptera). Although many bats eat insects in the family that contains mosquitoes (Diptera), most bats don't seem to have a strong liking for mosquitoes. Bats have been reported to eat small quantities of mosquitoes in locations throughout the country, including Alaska, Oregon, California, Michigan, Indiana, New Hampshire, New York, and Florida.

The species most likely to eat mosquitoes in Florida is the southeastern bat (Myotis austroriparius). This species has been reported to consume more mosquitoes than any other bat in any other state. They may resort to mosquitoes more often on colder nights when other insects are unavailable.

Given the small quantities of mosquitoes consumed by most bats, it is unlikely that bats would be effective at controlling large mosquito populations. However, large colonies of bats will certainly reduce the number of insects nearby. Bats are beneficial for insect control not only because they consume large quantities of insects, but because many insects avoid areas where they hear bat calls. Therefore, attracting bats to an area where a natural form of insect control is desired can be a smart idea.

\section{What Can You Do to Attract Bats?}

Bats roost in both naturally occurring and man-made structures. Natural structures used by bats include caves, rock crevices, hollows inside live and dead trees, palm fronds, and clumps of Spanish moss. Man-made structures used by roosting bats include mines, bridges, culverts, buildings, and specially made bat houses. These areas should be left undisturbed if you want to attract bats. 
In Florida, the bats most likely to consume agricultural pests are the Brazilian free-tailed bat and the big brown bat. Brazilian free-tailed bats are common throughout the state and tend to live in very large groups. Big brown bats are less common than Brazilian free-tailed bats in Florida; they tend to live in smaller groups, and they are more common in the northern half of the state than the southern. Both of these species roost most often in man-made structures such as bridges, attics, stadiums, picnic shelters, barrel tile roofs, and bat houses.

The species of bat in Florida most likely to consume mosquitoes is the southeastern bat. This species is common in northern Florida, less common in the central part of the state, and absent from south Florida. These bats often roost in caves, bridges, and culverts, and sometimes in tree cavities, buildings, and artificial bat houses. They usually feed near water.

All three of the bat species most likely to provide beneficial pest control services often make use of bat houses (Figure 2). This is good news for anyone interested in attracting these bats. Small bat houses are relatively simple to build and the materials required are fairly inexpensive (http://edis.ifas.ufl.edu/UW290 - "Effective Bat Houses for FL" EDIS). Manufactured bat houses are available at many stores and also online.

However, many pre-made houses will not attract bats because of poor design or construction. The Bat Conservation International website (www.batcon.org) lists vendors who sell bat houses with characteristics proven to be attractive to bats.

An added bonus of attracting bats to your property is the guano that will accumulate underneath the roost once bats have taken up residence. With a 10-3-1 NPK composition, bat guano is a potent organic fertilizer that you will obtain free of charge.

\section{Additional Sources of Information}

Allen, G. M., and M. B. Main. 2004. Bats of Florida. University of Florida, IFAS Extension document UW203 available at http://edis.ifas.ufl.edu/UW203.

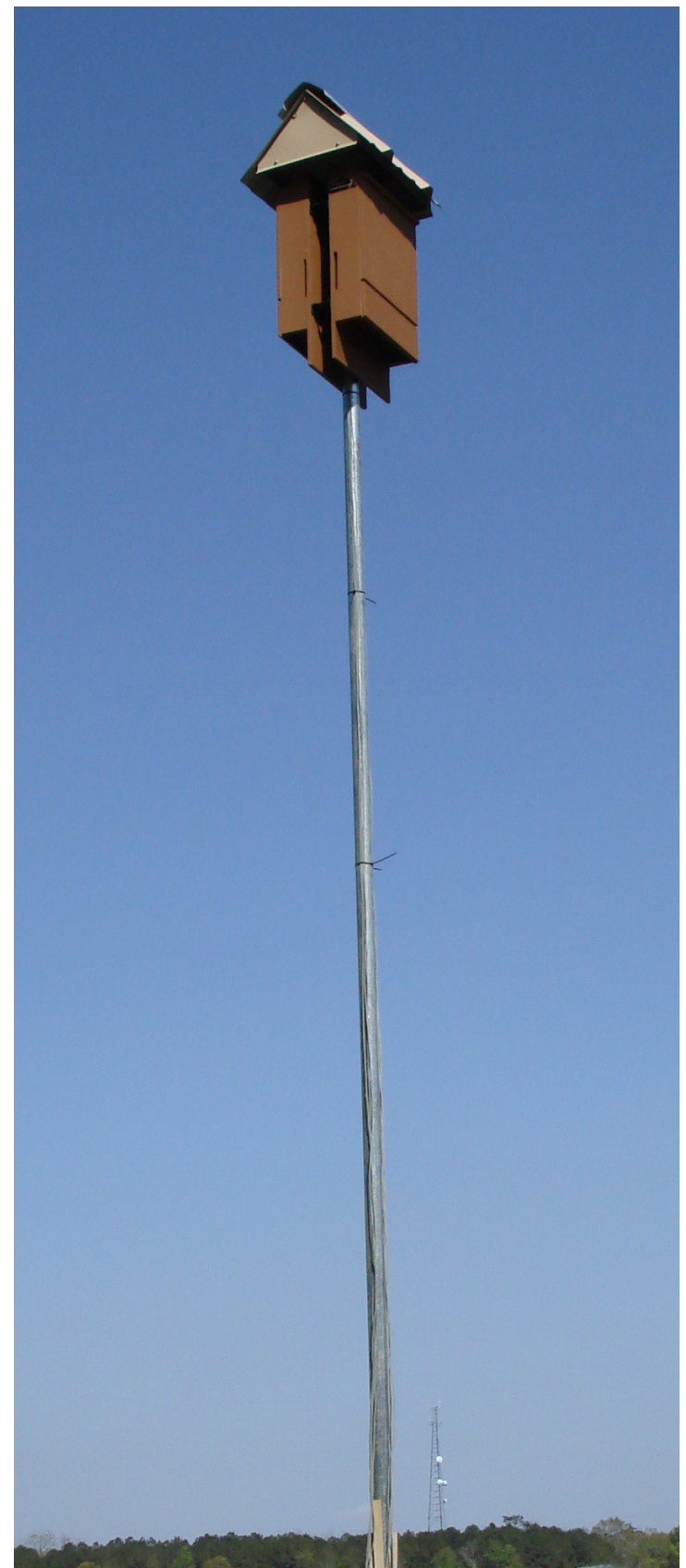

Figure 2. Two bat houses mounted back to back on a tall pole may attract bats Credits: Holly Ober (2008).

Cleveland, C. J., M. Betke, P. Frederico, et al. 2006. Economic value of the pest control service provided by Brazilian free-tailed bats in south-central Texas. Frontiers in Ecology and the Environment 4: 238-243.

Kern, W. H. 2005. Bats in buildings. University of Florida, IFAS Extension document MG342 available at http://edis.ifas.ufl.edu/MG342. 
Marks, C. S., and G. E. Marks, Bats of Florida. 2006. University Press of Florida. Gainesville, Fl. $176 \mathrm{pp}$.

Ober, H. K. 2008. Effective bat houses for Florida. University of Florida, IFAS Extension document WEC 246 available at http://edis.ifas.ufl.edu/UW290.

Ober, H. K., and F. J. Mazzotti. 2008. Conservation of bats in Florida. University of Florida, IFAS Extension document WEC247 available at http://edis.ifas.ufl.edu/UW291.

Rutledge, C. R. 2003. Mosquito control devices and services for Florida homeowners. University of Florida, IFAS Extension document IN171 available at http://edis.ifas.ufl.edu/IN171.

Zinn, T. L., and S. R. Humphrey. 1981. Seasonal food resources and prey selection of the southeastern brown bat (Myotis austroriaprius) in Florida. Florida Scientist 44: 81-90. 